\title{
Thérèse Malachy, Molière face au pouvoir. Un cas de
} figure: «Tartuffe»

\section{Lagier}

\section{(2) OpenEdition}

10 Journals

\section{Édition électronique}

URL : http://journals.openedition.org/studifrancesi/36042

DOI : 10.4000/studifrancesi.36042

ISSN : 2427-5856

Éditeur

Rosenberg \& Sellier

\section{Édition imprimée}

Date de publication : 1 juillet 2005

Pagination : 155-156

ISSN : 0039-2944

\section{Référence électronique}

M. Lagier, "Thérèse Malachy, Molière face au pouvoir. Un cas de figure: "Tartuffe» », Studi Francesi [En ligne], 145 (XLIX | I) | 2005, mis en ligne le 30 novembre 2015, consulté le 19 avril 2021. URL : http:// journals.openedition.org/studifrancesi/36042 ; DOI : https://doi.org/10.4000/studifrancesi.36042

Ce document a été généré automatiquement le 19 avril 2021.

\section{(c) $(1) \&$}

Studi Francesi è distribuita con Licenza Creative Commons Attribuzione - Non commerciale - Non opere derivate 4.0 Internazionale. 


\title{
Thérèse Malachy, Molière face au pouvoir. Un cas de figure: «Tartuffe»
}

\author{
M. Lagier
}

\section{RÉFÉRENCE}

THÉRÈSE MALACHY, Molière face au pouvoir. Un cas de figure: «Tartuffe», «Revue d'histoire du théâtre», janvier-juin 2004, pp. 105-110.

Dans le cadre d'un numéro consacré aux Théâtres interdits et secrets, Th. Malachy revient sur les difficultés rencontrées par Molière avec Tartuffe, pour rappeler en quoi le contexte politique et religieux peut expliquer l'intensité exceptionnelle des polémiques suscitées par la pièce. Bien que le pouvoir soit déjà centralisé, le jeune Louis XIV a besoin de consolider sa position et d'affirmer son autorité tout en tenant compte du parti dévot auquel appartient sa mère. Par ailleurs gallicans et jansénistes se rejoignent pour condamner les auteurs dramatiques et les comédiens, et la Compagnie du SaintSacrement, bien que devenue clandestine, se montre très active. Molière de son côté ne fait rien pour arranger les choses avec Dom Juan et Le Misanthrope mais Th. Malachy refuse de voir en lui un révolutionnaire. Certes c'est un esprit frondeur qui attaque ceux qui s'opposent à lui et à son art, et qui exprime au travers de ses œuvres son désir d'un monde gouverné par des lois plus naturelles, mais la bataille de Tartuffe met surtout aux prises le roi et le pouvoir religieux dans un affrontement dont Molière fait les frais parce que le théâtre est un phénomène majeur de la vie publique de l'époque. 